\title{
Participatory Rural Appraisal (PRA) For The Development Of Safe Weaving Bamboo Production Through Community Empowerment To Improve Health And Safety Of Bamboo Weaving Craftsmen In Mojorejo, Ponorogo,East Java, Indonesia
}

\author{
Rindang Diannita ${ }^{1 *}$, Mohammad Muslih ${ }^{2}$, Neri Wijayanti ${ }^{3}$, Umma Fatayati $^{4}$ \\ ${ }^{1}$ Occupational Safety and Health Department, Faculty of Health Science \\ Universitas Darussalam Gontor, Indonesia \\ ${ }^{2}$ Aqidah \& Islamic Philosophy Department, Faculty of Ushuluddin \\ Universitas Darussalam Gontor, Indonesia \\ ${ }^{3}$ Islamic Education Department, Faculty of Tarbiyah \\ Universitas Darussalam Gontor, Indonesia \\ ${ }^{4}$ Agrotechnology Department, Faculty of Science \& Technology \\ Universitas Darussalam Gontor, Indonesia \\ ${ }^{*}$ Corresponding Author: \\ Email: rindangdiannita@unida.gontor.ac.id
}

\begin{abstract}
A Community service program (PKM) is a program designed for community empowerment. Mojorejo Village, Ponorogo Regency, East Java, Indonesia, is a village with bamboo producers and human resources who have expertise as woven bamboo craftsmen. The community service program aims to develop safe woven bamboo production, with the ultimate goal of increasing the income of the community in Mojorejo Village and reducing the risk of work accidents for bamboo woven craftsmen. This program uses a Participatory Rural Appraisal (PRA) approach, and identification of potential hazards, where in the program implementation it uses focus group discussions, training, socialization, counseling, and mentoring. The result of this program is an increase in the health and safety of woven bamboo craftsmen and an increase in the community's economy through product development.
\end{abstract}

Keywords: Participatory Rural Appraisal (PRA), Bamboo, Safety

\section{INTRODUCTION}

Woven bamboo is one of the heritages that has survived since the colonial era of the Dutch East Indies, as one of the traditional handicraft products, which is recorded in Indonesian cultural heritage [1] Another benefit of bamboo is give sound basis decision to engineers to apply the Bamboo in construction materials and building decoration. It supports the economy in Indonesia specifically with significant labor absorption potential of using locally produced bamboo building material as alternative to wood constructional material in Japan [2] [3] [4] Community development is a way to mobilize and preserve village potential, which is stated in Law number 6 of 2014 that every village needs to develop its potential more independently in order to realize prosperity, community independence, and preserve culture [5] In February 2020, the 
workforce was 137.91 million people, while the working population was 131.03 million, with 74.04 million people (56.5\%) working in informal activities [3] Woven Bamboo is part of an industry that has an impact on people's welfare.

Mojorejo woven bamboo is one of the medium-sized industries. Economic activity is carried out by converting basic goods into finished or semi-finished goods into goods of higher value [6] The community processes bamboo into woven products in the form of sieves, boboko, picnic baskets, nyiru, pipiti, and parcel boxes, as well as non-woven products such as piggy banks, key chains, glasses, frames, teapots, letter boxes, and tissue holders. The average added value of woven products is Rp. $131,197.21$ or $9.11 \%$ of the average value added of non-woven products of Rp. $1,439,742.42$. The average value added ratio of woven products is 0.83 while the average value added ratio of non-woven products is 0.90 . The process of woven bamboo is mostly carried out by the community as bamboo woven craftsmen. Woven crafts are marketed more broadly than other bamboo products, especially for household furniture products [7] Mojorejo Village is one of the villages located in Jetis District, Ponorogo Regency, East Java, Indonesia (Figure 1), located in a strategic location. The area in Mojorejo Village is proclaimed as a tourist village and the largest woven producing area in Indonesia besides Banyuwangi, Kudus, Tangerang, Padang, Tasikmalaya, Buleleng Bali [8]
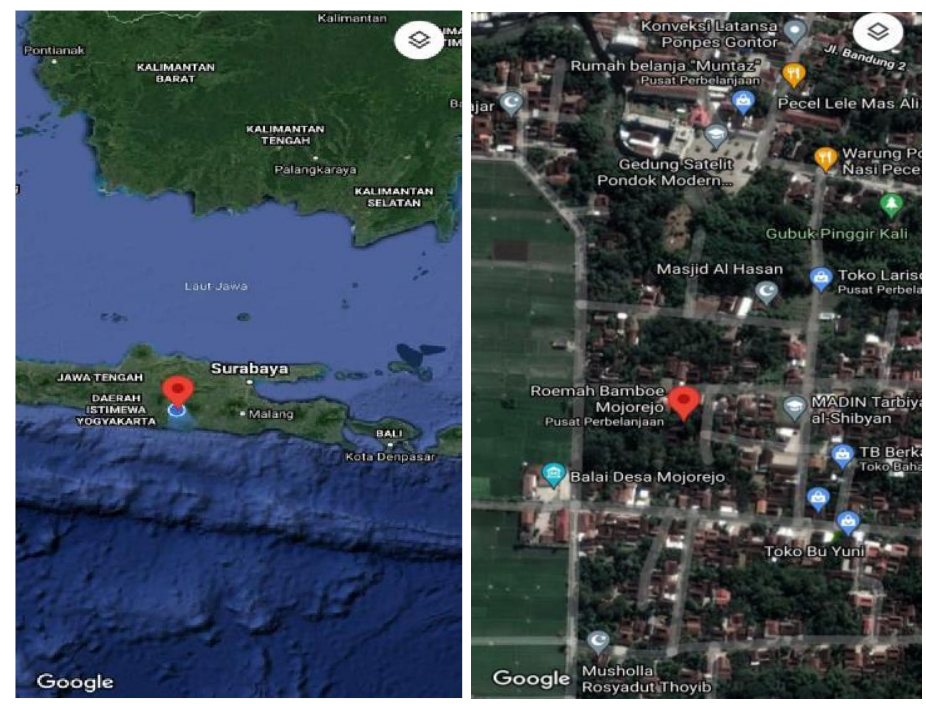

Fig 1. Location of Mojorejo Village, Jetis

Ponorogo Regency, East Java, Indonesia

In general, the profile of Roemah Bmaboe, (a) The location is in the village of Mojorejo covering an area of 101 ha with the majority of people working in agriculture and for generations, the main work of the residents of Mojorejo Village is as farmers and woven bamboo craftsmen. (b) Raw materials, the types of raw materials used are bamboo of various sizes, obtained from bamboo cultivation in Mojorejo village and supply of bamboo from surrounding villages. (c) Human Resources in the form of 
craftsmen in Mojorejo Village are approximately 30 craftsmen, consisting of PKK women, and housewives around Mojorejo village, who are elderly women. Which allows for work accidents in the form of slashing a knife, scratched by a sharp object. As the main occupation and an increase in people's income, safety and health at work are important. The New Normal era has become a new term in the world which means efforts to change behavior or habits and carry out activities as usual but by implementing health protocols in the form of using

Personal Protective Equipment (PPE) in the form of masks, gloves, always washing hands, and other efforts related to behavior. safe and healthy. The production process of woven bamboo in Roemah Bmboe, Mojorejo village was done manually. The process of taking bamboo to preparation for production, cutting was done with sharp objects such as machetes, machetes, sickles, and knives. This increases the risk of work accidents during the production process. Most of the women who produce woven bamboo are elderly women. Sitting position that is not ergonomic for a long time causes many complaints of pain in the spine or low back pain [9] Potential hazards of Occupational safety and health $(\mathrm{OSH})$ must be implemented in all workplaces, both formal and informal [3] So that socialization and counseling are needed to improve work safety for woven bamboo craftsmen, at least having insight related to safety, health and work safety. Therefore, to solve the problems above, this community service program aims to improve the health and safety of Bamboo Weaving Craftsmen in Mojoejo Village as a Bamboo Weaving-Based Packaging Production Center.

\section{METHODS}

Using the Participatory Rural Appraisal (PRA) approach., is a community development method whose problems are identified by the community itself and the solution is used by the community again [10]

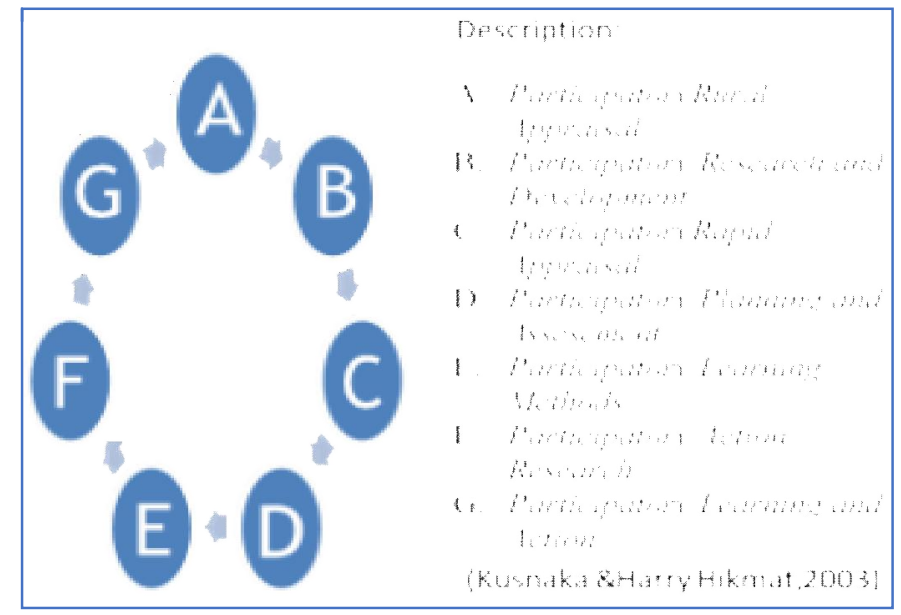

Fig 2. Participatory Rural Appraisal (PRA)

Source: Kusnaka and Harry Hikmat, 2003 
As for the implementation of community service programs used in the form of socialization, counseling, Focus Group Discussion (FGD), training, and mentoring, consisting of (a) activity plans (b) approach methods (c) partner roles.

Table 1. Implementation Method

\begin{tabular}{|c|c|c|}
\hline Approach & Method & Activity \\
\hline $\begin{array}{lr}\text { Discussions } & \text { related to } \\
\text { community } & \text { service } \\
\text { programs } & \end{array}$ & $\begin{array}{c}\text { Focus Group } \\
\text { Discussion (FGD) }\end{array}$ & $\begin{array}{l}\text { Active role in providing information } \\
\text { about problems in Mojorejo Village } \\
\text { and Facilitator for FGD activities }\end{array}$ \\
\hline $\begin{array}{lr}\text { Socialization } & \text { of } \\
\text { Occupational Safety and } \\
\text { Health and Personal } \\
\text { Protective Equipment (PPE) }\end{array}$ & Socialization & $\begin{array}{l}\text { Participants in the socialization } \\
\text { activity for craftsmen, and activists in } \\
\text { Mojorejo Village }\end{array}$ \\
\hline $\begin{array}{l}\text { In-depth education on } \\
\text { hazards and risks }\end{array}$ & Counseling & $\begin{array}{l}\text { Participants in Extension activities for } \\
\text { craftsmen, and activists in Mojorejo } \\
\text { Village }\end{array}$ \\
\hline $\begin{array}{l}\text { Training on the correct and } \\
\text { standardized use of Personal } \\
\text { Protective Equipment (PPE) }\end{array}$ & Training & $\begin{array}{l}\text { Implement and practice the use of } \\
\text { Personal Protective Equipment (PPE) } \\
\text { for Work Safety }\end{array}$ \\
\hline $\begin{array}{l}\text { Safe and healthy work } \\
\text { assistance }\end{array}$ & Mentoring & $\begin{array}{l}\text { Ensuring Occupational } \\
\text { practices are implemented }\end{array}$ \\
\hline
\end{tabular}

\section{Source: Researcher Data}

Potential analysis is the stage of observing and seeing all the potential and problems using the Hazard Identification and Risk Assessment (IBPR) for Improving the safety and health of woven bamboo craftsmen and risk analysis, assessing (a) hazard identification (b) risk identification (c) control. Hazard identification and risk assessment are the basis for determining occupational safety risk management in the work environment and programs, this management is arranged based on the level of risk that exists in the work environment. With the aim of eliminating or minimizing any existing hazards [11]

\section{RESULT AND DISCUSSION}

The number of woven bamboo craftsmen has decreased compared to 10 years ago. Generally, they are parents who inherited their skills as woven bamboo craftsmen from their parents. The woven bamboo craft, as an ancestral cultural "inheritance", which provides the progress of the community and village, and has a high economic value. A positive trend with increasing bamboo fiber percentage with optimum value at $9 \%$, material which can be used for the application like the roof, manhole, chemical containers.Bamboo is one product non-timber forest products that have value economy, available in large quantities, widely distributed and has many benefits, but many craftsmen pay less attention to safety and health at work [12] The woven bamboo 
craft is estimated to be "extinct" if it is not preserved. Occupational Health and Safety is one of the topics that is never finished being discussed in various parts of the country. The existence of the World Health Organization (WHO) is proof that the health sector has a "special place" for serious discussion, Occupational health and safety is a component of the hospital that must be considered [13] Mojorejo village as a place for woven bamboo craftsmen, to discuss and develop in several aspects, namely improving the quality of handicraft products, increasing product marketing, developing business partnerships, utilizing capital loan facilities [9]
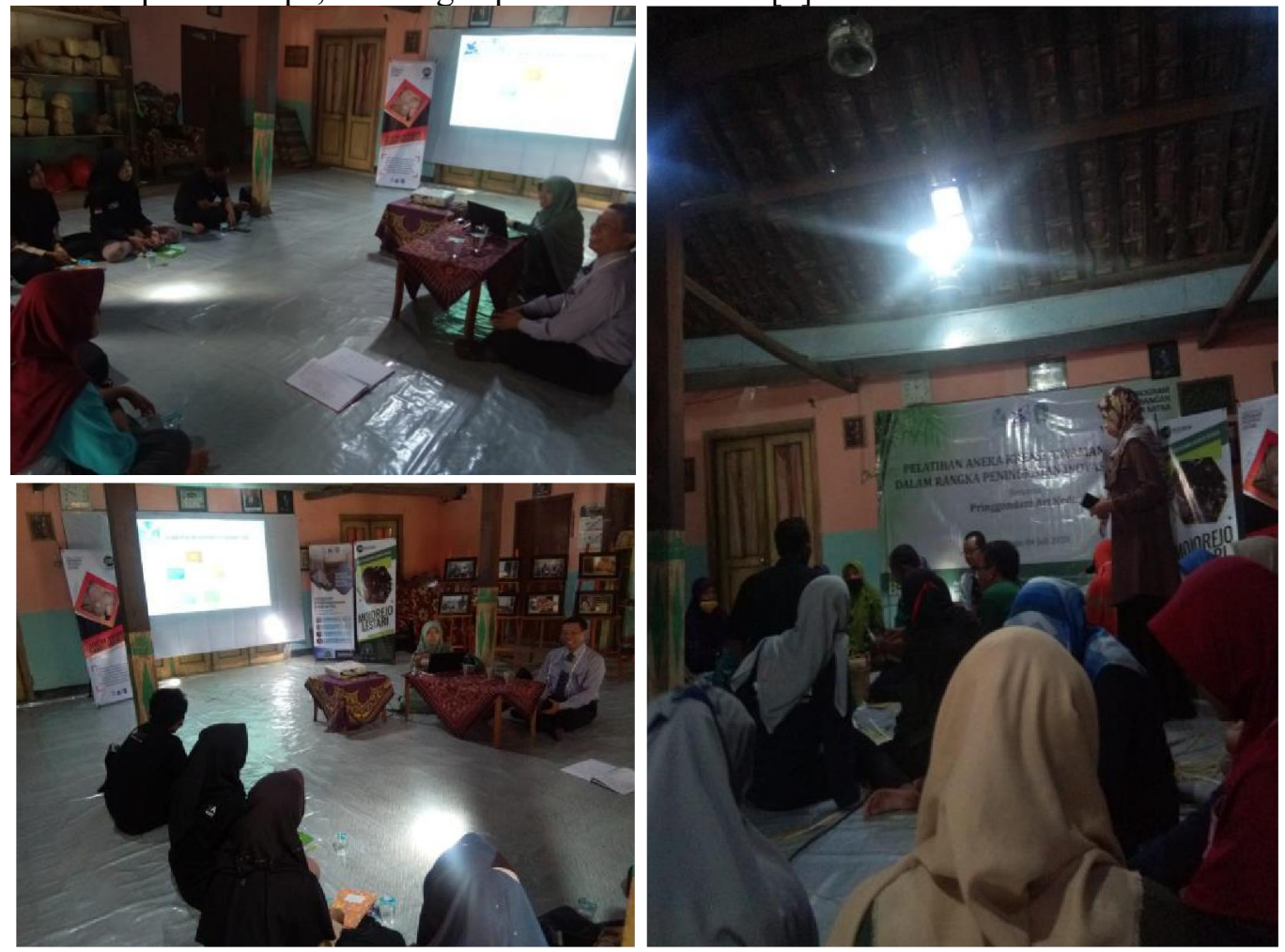

Fig 3. The atmosphere of Community Service activities

in the form of socialization, counseling, training related to Occupational Safety and

Health and Personal Protective Equipment (PPE)

Programs that have been implemented : first, Socialization of Occupational Safety and Health and Personal Protective Equipment (PPE), second, in-depth counseling related to hazards and risks, third, training on the correct and standardized use of Personal Protective Equipment (PPE).

\section{Participatory Rural Appraisal (PRA)}

The woven bamboo craftsmen continue to make modifications so that there is added value from the woven bamboo products, along with the increasing demand and adding new variants, in order to meet new product variants to the community. Method participatory is a PRA method that can act as a facilitator and can directly facilitate residents in recognizing and utilizing participatory method to develop a Community 
Action Plan (CAP), which will later become a tourism village development program. At the end of the implementation of this program, successfully compiled the CAP for the development of a tourism village based on local culture and serves to form the management of the tourism village development organization assisted by several local election facilitators [14] The training target can target the craftsmen of Mojorejo village, with the following programs:

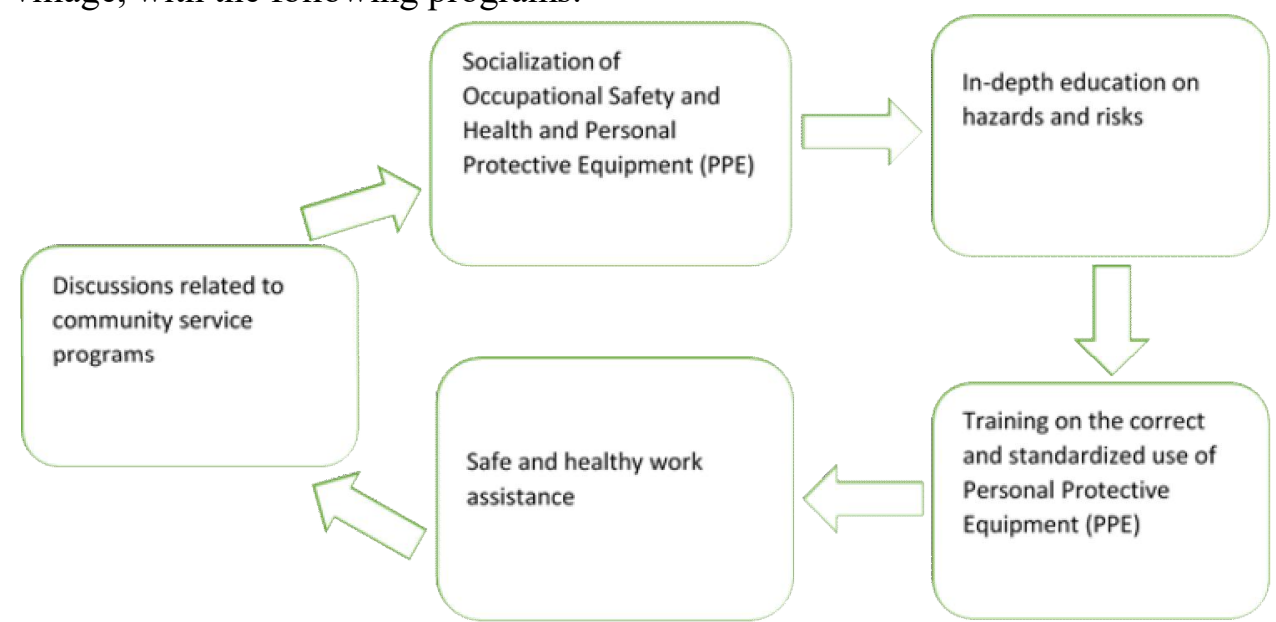

Fig 4. Community Service Program

In the implementation of this Community Service, with the Participatory Rural Appraisal (PRA) method, researchers can act as facilitators and can directly facilitate residents in recognizing, utilizing, and compiling tourism village development programs. The method of implementing activities by directly visiting each partner's business location for socialization, training, mentoring and discussion activities, as well as monitoring evaluation, is one method of community service [14] [15] Through discussions in the Participatory Rural Appraisal (PRA) activity, the craftsmen of Mojorejo Village also understand that a tourist village must be built for mutual prosperity, and to preserve the increasingly extinct woven bamboo. Thus, the participation of citizens to gain economic and social benefits and the benefits of the presence of guests can be used to finance community development.With the implementation of some of the above activity programs, the community can finally feel an increase in the economy, and the craftsmen feel the benefits. Conditions like this further encourage the growth of woven bamboo crafts (1) ease of selling or collecting products (2) ease of obtaining raw materials (3) formation of tourist villages (4) opening of new wider market shares (5) preserving the heritage of woven bamboo (6) have insight and awareness related to occupational safety and health.

\section{Safely Woven Bamboo Process}

Bamboo is a fastest growing grass species and is an important forest type in the tropical and subtropical regions of Africa, Asia, and Central and South America and an integral part of forestry, but it is also widespread outside the forests, including on farmlands, riverbanks, roadsides and urban areas [16] Every workplace, both formal 
and informal, has various potential hazards that can affect the health of workers or can cause occupational diseases, from various activities of bamboo craftsmen. The risks of work accidents that occur in Mojorejo Village due to manual weaving of bamboo are as follows: slashed hands and feet, stabbed by bamboo blades, injured by work equipment, exposed to sharp objects when cutting bamboo, sitting position is not ergonomic causing low back pain., Lifting bamboo/ heavy objects cause muscle injury

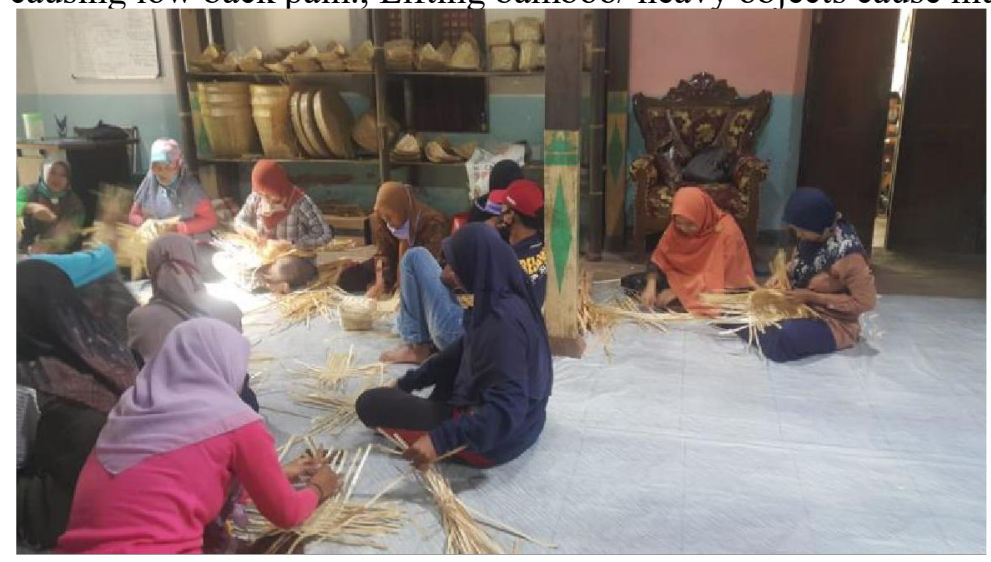

Fig 5. A woven bamboo craftsman is weaving

with a bent sitting position that is not ergonomic

The production process of woven bamboo in Roemah Bmboe was done manually. The process of taking bamboo in bamboo cultivation was done manually, cutting bamboo into small pieces, cutting was done with sharp objects such as machetes, machetes, sickles, and knives until production preparation was done manually. The flexural strength against various stacking sequences of woven bamboo layers [2] This increases the risk of work accidents and occupational diseases during the production process. Sitting position that is not ergonomic for a long time, causes many complaints of pain in the spine. result of the wrong sitting position in order to reduce the occurrence of low back pain. [9] [17] The following is an analysis of potential problems using Hazard Identification and Risk Assessment as follows:

(1) Cut hands and feet, hit by sharp objects due to woven equipment (Craftsman injured, cut, limb injury) : Use personal protective equipment (PPE) in the form of gloves

(2) Punctured by bamboo blades and exposed to sharp objects when cutting bamboo (Craftsman injured, cut, limb injury) : Using Personal Protective Equipment (PPE) in the form of gloves, aprons, masks

(3) Affected by spiky bamboo on the limbs (Craftsman injured, cut, limb injury) : Using Personal Protective Equipment (PPE) in the form of aprons, masks

(4) Ergonomic sitting position causes low back pain (Low back pain and muscle injury) : Improve sitting position, straight back, sit with a chair with a backrest

(5) Lifting bamboo/heavy objects (Low back pain and muscle injury) : Lifting using feet as axle. Lifted in a squat position first, back straight, place objects parallel to the 
chest for ergonomics, use a pedestal so that objects do not directly hit the body, with a non-ergonomic sitting position has a risk of experiencing Low Back Pain (LBP) as much as $(50.0 \%)$ greater than the ergonomic sitting position with a p-value of 0.021 , and an OR value of 0.125 [17]
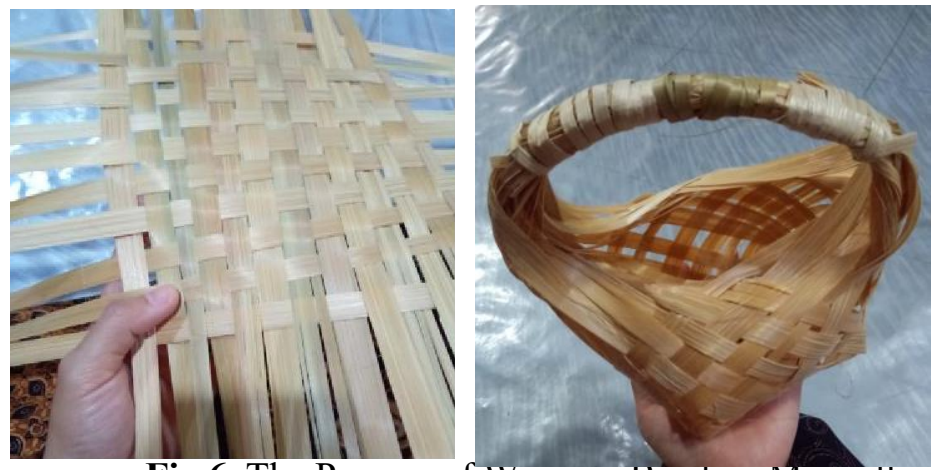

Fig 6. The Process of Weaving Bamboo Manually

Potential hazards that can affect the health of workers or can cause occupational diseases in bamboo woven craftsmen. The bamboo blades are sharp, craftsmen must be very careful in treating bamboo as woven material, because the risk of accidents such as slashed hands, stabbed by bamboo blades, and the risk of other potential mechanical hazards can occur. The purpose of this study is to analyze the risks of occupational safety and health on weaving craftsmen [11] Training as a means to build programs village with priority positioning the community as actors, outsiders as facilitators, and principles practical orientation, in the sense of community discussion, namely solving problems and develop activities that can be implemented by the community. Efforts in terms of ensuring and protecting occupational safety and health for workers by implementing occupational safety and health, for workers, as well as the environment in hospitals in the form of efforts to prevent work accidents and occupational diseases from all forms of activities that pose a hazard [14] [18]

In the Focus Group Discussion (FGD) meeting, the discussion forum already has a view regarding the importance of developing a healthy and safe tourist village. By using Participatory Rural Appraisal (PRA) the program begins with, analyzing potential, preparing plans, compiling work plans, and evaluating, as follows:

(1) Potential analysis is the stage of observing and seeing all the potential, conditions that exist and are owned by Mojorejo village, in the form of natural resources, namely bamboo, human resources, namely woven bamboo craftsmen, available infrastructure for Mojorejo Village basecamp, improvement of cultural arts and heritage.

(2) Deliberation of consensus is carried out after analyzing the potential in the village of Mojorejo, namely agreeing on something strength from the village to be ready to be promoted to outside parties, namely the availability of raw materials in the form of bamboo.

(3) preparation of activity plans, namely activity plans in the form of innovations for Mojoreo village woven products, with safe and healthy working 
methods, plans for implementing activities that prioritize occupational safety and health, by procuring personal protective equipment (PPE) in the form of gloves, masks, body armor.

(4) evaluation of activities in the form of socialization, counseling, training, and assistance to craftsmen in Mojorejo Village so that they can develop into a safe Tourism Village by prioritizing occupational safety and health.

Bamboo is commonly considered as a green, environmentally friendly material. the importance of bamboo with the perceive benefits. The study found the most important, wood base in the industry from the businessmen. So we might say the applications bamboo was very important for the country according to the respondent's responses and also the benefits for the businessmen. Therefore, if the country could embrace this alternative, it will be a great opportunity for the population [19] [20]

\section{CONCLUSION}

Bamboo woven craftsmen in Mojorejo Village can benefit greatly from the presence of a bamboo packaging production center Mojorejo Village. Home crafts in the form of woven bamboo crafts are preserved and bamboo woven craftsmen are increasing. Gradually, awareness about safety in weaving bamboo will increase and reduce work accidents and occupational diseases in bamboo weaving craftsmen. In addition, woven bamboo products can be made in various variations, so that woven bamboo products can be accepted in national and international markets, and can be a driving force for the economy of craftsmen and the people of Mojorejo Village.

\section{ACKNOWLEDGMENTS}

Thank you to the DRPM Kemenristek-Brin for their trust in the Community Service Program, thank you for the support from Mojorejo Village, Karang Taruna, Chairperson of the Mojorejo Village.

\section{REFERENCES}

[1] Ministry of the Republic of Indonesia, "Cultural Heritage Ministry of the Republic of Indonesia." Link: https://warisanbudaya.kemdikbud.go.id/?newdetail\&detailCatat=2353

[2] M. M. . M. A. Aidy Ali a, Kannan Rassiah b, "The Effect Of Stacking Sequence Of Woven Bamboo On Mechanical Behavior Of Fiber-Reinforced Composites," 2021.

[3] I. Sriagustini and T. Supriyani, "Assistance in identifying potential occupational safety and health hazards for woven bamboo craftsmen in Tasikmalaya," vol. 5, no. 2, pp. 251-255, 2021.

[4] N. I. Slamet, "Examining the Potential of Strand Woven Bamboo As," no. March, 2012.

[5] Ministry of the Republic of Indonesia, "Law Number 6 of 2014 concerning Villages," ACM Int. Conf. Proceeding Ser., vol. 18-April-2, no. 1, pp. 45-54, 2016, doi: 10.1145/2904081.2904088.

[6] Statistics Center Republic of Indonesia, Data Strategis BPS 2012. .

[7] T. Widyaningsih, "Processing and Added Value of Bamboo in Tasikmalaya, West 
Java,” J. Wasian, vol. 7, no. 1, pp. 51-63, 2020, doi: 10.20886/jwas.v7i1.5539.

[8] E. M. Zamroni Salim, Agency for the Study and Development of Trade of the Republic of Indonesia. 2017.

[9] M. Muslih, U. Etica, E. Rosanti, E. W. Hastuti, and W. Mubarok, "Pengembangan Sentra Produksi Kemasan Berbasis Anyaman Bambu Melalui Pemberdayaan Karang Taruna dan PKK untuk Peningkatan Ekonomi Masyarakat di Desa Mojorejo Kecamatan Jetis Kabupaten Ponorogo," Engagem. J. Pengabdi. Kpd. Masy., vol. 4, no. 2, pp. 343362, 2020, doi: 10.29062/engagement.v4i2.222.

[10] P. Kuipers, E. Kendall, and T. Hancock, "Developing a rural community-based disability service: (I) service framework and implementation strategy," Aust. J. Rural Health, vol. 9, no. 1, pp. 22-28, 2001, doi: 10.1046/j.1440-1584.2001.00333.x.

[11] I. Sriagustini and T. Supriyani, "The Risk Assessment on Bamboo Weaving Craftsmen in Rajapolah District Tasikmalaya Regency,” Indones. J. Occup. Saf. Heal., vol. 10, no. 1, p. 64, 2021, doi: 10.20473/ijosh.v10i1.2021.64-78.

[12] E. Doni, G. Hardiansyah, and M. Idham, "Analisis Pendapatan Masyarakat Pengrajin Anyaman Bambu Di Desa Engkahan Kecamatan Sekayam Kabupaten Sanggau,” J. Hutan Lestari, vol. 6, no. 4, pp. 814-825, 2018, [Online]. Available: https://jurnal.untan.ac.id/index.php/jmfkh/article/view/29475.

[13] R. Diannita, I. Indasah, and S. Siyoto, "Analysis of Work Accidents Based on K3 Knowledge and Work Behavior at Muhammadiyah Hospital in Ponorogo," J. Qual. Public Heal., vol. 3, no. 2, pp. 383-389, 2020, doi: 10.30994/jqph.v3i2.87.

[14] B. Hudayana et al., "Participatory Rural Appraisal (PRA) untuk Pengembangan Desa Wisata di Pedukuhan Pucung, Desa Wukirsari, Bantul," Bakti Budaya, vol. 2, no. 2, p. 3, 2019, doi: 10.22146/bb.50890.

[15] L. T. Harinie, A. Hukom, and J. Juma'eh, "Pendampingan dalam Memasarkan Produk Hasil Usaha UKM melalui Penggunaan Media Sosial di Kabupaten Gunung Mas Kalimantan Tengah," Engagem. J. Pengabdi. Kpd. Masy., vol. 4, no. 1, pp. 51-59, 2020, doi: 10.29062/engagement.v4i1.179.

[16] K. Paudyal et al., "Framework for assessing ecosystem services from bamboo forests Lessons from Asia and Africa W O R K I N G P A P E R 25 5," Inbar.Int, p. BARBOSA, A. et al. Cost-effective restoration and, [Online]. Available: https://www.inbar.int/wp-content/uploads/2020/05/1573091377.pdf.

[17] P. Anggraika, "Hubungan Posisi Duduk Dengan Kejadian Low Back Pain (LBP) Pada Pegawai Stikes," J. 'Aisyiyah Med., vol. 4, no. 1, pp. 1-10, 2019, doi: 10.36729/jam.v4i1.227.

[18] R. Diannita, "Analisis Illumination Level Terhadap Kecelakaan Kerja Di Rumah Sakit XYZ Indonesia," vol. 5, no. 1, 2020.

[19] L. Shen, J. Yang, R. Zhang, C. Shao, and X. Song, "The benefits and barriers for promoting bamboo as a green building material in China- An integrative analysis," Sustain., vol. 11, no. 9, 2019, doi: 10.3390/su11092493.

[20] D. Francois and S.-Y. Liaw, "Important Applications and the Perceived Benefits of Bamboo: A Comparison between Consumers and Businessmen," Int. J. Bus. Manag., vol. 14, no. 6, p. 12, 2019, doi: 10.5539/ijbm.v14n6p12. 